UDC: $\mathbf{3 1 6 . 7 7 2 . 4}$

DOI: https://doi.org/10.32689/2617-

2224-2020-1(21)-97-106

Свдокимова Валентина Володимирівна, кандидат соціологічних наук, доцент кафедри соиіальної роботи та педагогіки Інституту соціальних технологій Відкритого міжнародного університету розвитку людини “Україна", 03115, м. Київ, вул. Львівська, 23, тел.: +38 (050) 44072 24, e-mail: evvv@evdokimova. kiev.ua

ORCID 0000-0002-0468-613X

Евдокимова Валентина Владимировна, кандидат социологических наук, доцент кафедры сочиальной работь и педагогики Института социальных технологий Открытого международного университета развития человека "Украина", 03115, г. Киев, ул. Львовская, 23, тел.: +38(050) 44072 24, e-mail: evvv@ evdokimova.kiev.ua

Ievdokymova Valentyna Volodymyrivna, candidate of sociological sciences, Associated Professor, Open international university of human development "Ukraine", 03115, Kyiv, Str. Lvivska, 23, tel.: +38 (050) 44072 24, e-mail:evvv@evdokimova.kiev.ua

ORCID 0000-0002-0468-613X

\title{
АРХЕТИПИ ПРИНЦИПІВ СОЦІАЛЬНОЇ СПРАВЕДЛИВОСТІ НА ПРИКЛАДІ УДОСКОНАЛЕННЯ АДРЕСНОСТІ СОЦІАЛЬНИХ ВИПЛАТ
}

Анотація. Розглянуто основні підходи до призначення та виплати адресної соціальної допомоги в Україні.

Звернено увагу на те, що незважаючи на удосконалення надання адресної соціальної допомоги, ефективність їх виплати залишається проблемою.

Розглянуто принцип удосконалення соціальної справедливості при наданні адресної соціальної допомоги з точки зору морально-етичних підходів. 
Особливої уваги надано принципу практичного впровадження адресності, якими керується українська держава при наданні соціальної допомоги.

Визначено з соціологічної точки зору недоліки і переваги впровадження першої адресної соціальної програми в Україні, а саме, впровадження програми надання субсидій на житлово-комунальні послуги, яка почала діяти з $1995 \mathrm{p}$.

Окреслено, що в Україні вже існують випадки повернення соціальних виплат у бюджет за недобросовісний характер їх отримання.

Наведено одностайну думку науковців щодо удосконалення системи соціальних виплат і допомог в Україні задля досягнення соціальної ефективності суспільства.

Розглянуто позитивні приклади морально-етичних та культурних підходів самовизначення щодо оформлення адресної соціальної допомоги.

Обгрунтовано необхідність застосування морально-етичного підходу до громадян, які претендують на отримання адресних соціальних допомог, зокрема, за запитом до правоохоронних органів. Якщо соціальна поведінка не відповідає загальноприйнятим стандартам поведінки, пропонується замінити адресну соціальну допомогу непривабливими для суспільства роботами 3 виховною метою, метою дотримання принципу соціальної справедливості і надання засобів до існування.

Ключові слова: адресні соціальні виплати, удосконалення, практичне впровадження, успішна соціалізація, морально-етичні принципи.

\section{АРХЕТИПЫ ПРИНЦИПОВ СОЦИАЛЬНОЙ СПРАВЕДЛИВОСТИ НА ПРИМЕРЕ СОВЕРШЕНСТВОВАНИЯ АДРЕСНОСТИ СОЦИАЛЬНЫХ ВЫПЛАТ}

Аннотация. Рассмотрены основные подходы к назначению и выплате адресной социальной помощи в Украине.

Обращено внимание на то, что несмотря на совершенствование оказания адресной социальной помощи, эффективность их выплаты остается проблемой.

Рассмотрен принцип усовершенствования социальной справедливости при предоставлении адресной социальной помощи с точки зрения морально-этических подходов.

Особое внимание обращено на принципы практического внедрения адресности, которыми руководствуется украинское государство при предоставлении социальной помощи.

Определены, с социологической точки зрения, недостатки и преимущества внедрения первой адресной социальной программы в Украине, в частности, внедрение программы предоставления субсидий на жилищно-коммунальные услуги, которая начала действовать с 1995 г.

Очерчено, что в Украине уже существуют случаи возвращения социальных выплат в бюджет за недобросовестный характер их получения. 
Высказано единодушное мнение украинских ученых относительно системи социальных выплат и пособий в Украине совершенствования для достижения социальной эффективности общества.

Сделана попытка усовершенствования принципа социальной справедливости при предоставлении адресной социальной помощи с точки зрения морально-этических подходов.

Рассмотрены положительные примеры морально-этических и культурных подходов самоопределения по оформлению адресной социальной помощи.

Обоснована необходимость применения морально-этического подхода к гражданам, претендующим на получение адресных социальных пособий, в частности, по запросу в правоохранительные органы. Если социальное поведение не соответствует общепринятым стандартам, предлагается заменить адресную социальную помощь непривлекательными для общества работами с воспитательной целью, целью соблюдения принципа социальной справедливости и предоставления средств к существованию.

Ключевые слова: адресные социальные выплаты, совершенствование, практическое внедрение, успешная социализация, морально-этические принципы.

\section{THE ARCHETYPES OF SOCIAL JUSTICE PRINCIPLES ARE EXEMPLIFIED BY IMPROVING THE TARGETING OF SOCIAL BENEFITS}

Abstract. The article deals with the basic approaches to the appointment and payment of targeted social assistance in Ukraine. Attention is drawn to the fact that, despite the improvement of targeted social assistance, the effectiveness of their payment remains a problem.

Therefore, the purpose of the article is to attempt to improve the principle of social justice in providing targeted social assistance in terms of moral and ethical approaches. Attention is drawn to the principles of practical implementation of targeting, which guides the Ukrainian state in providing social assistance.

From a sociological point of view, the disadvantages and advantages of implementing the first targeted social program in Ukraine, namely, the implementation of a subsidy program for housing and communal services, which began to operate since 1995, have been examined. It is emphasized that in Ukraine there are already cases of return of social payments to the budget for the unfair nature of their receipt.

Ukrainian scientists, O. S. Bukhtiyarov, O. I. Danylyuk, S. M. Didyk, E. M. Libanova, O. M. Makarova and others are unanimous in that the system of the social payments and benefits in Ukraine needs to be improved in order to achieve social efficiency of the society. The ambiguity is only in how to achieve this improvement.

Positive examples of moral, ethical and cultural approaches to self-determination in addressing targeted social assistance have been considered. 
It is concluded that it is necessary to apply a moral and ethical approach to the citizens who claim to receive targeted social benefits, in particular, at the request of law enforcement agencies. If social behaviour does not meet generally accepted standards of behaviour, it is proposed to replace targeted social assistance with unattractive work for educational purposes, to comply with the principle of social justice and to provide livelihoods.

Keywords: targeted social payments, improvements, practical implementation, successful socialization, moral and ethical principles.

Постановка проблеми. Архетипи принципів соціальної справедливості в кожній країні формувалися як узагальненням власного досвіду, так і узагальненням позитивного досвіду інших країн. Кожна країна проходить тривалий час формування, становлення і розвитку соціальних відносин.

Починаючи з часів Незалежності в українському суспільстві ведуться дискусії щодо переходу на адресні соціальні допомоги.

Незважаючи на удосконалення надання адресних соціальних допомог, ефективність їх виплати залишається проблемою.

Аналіз останніх досліджень та публікацій. Українські вчені, такі як: Е. Лібанова, О. Макарова і ін. розглядають принципові засади реалізації соціальної політики в Україні; Е. Афонін, В. Бодров, В. Князєв, С. Попов, Ю. Сурмін, С. Серьогін, також системно розглядають і інші складові державного і публічного управління.

Практичне ж впровадження принципу адресності при наданні соціальної допомоги було, зокрема, підкреслено керівництвом Мінсоцполітики під час участі у Міжнародній конференції “Універсальні грошові виплати та виплати сім'ям 3 дітьми” 8 лютого 2019 [1].
Однією з перших адресних соціальних програм в Україні було впровадження програми надання субсидій на житлово-комунальні послуги, яка почала діяти з 1995 року.

Соціологічний аналіз якості надання цієї послуги через декілька років після її впровадження показав недоліки в українському варіанті іiі отримання і наразі діє більш досконалий механізм отримання цієї соціальної допомоги, яка вже з більшою вірогідністю надається тим, хто 111 потребуе [2].

На необхідності удосконалення механізму надання адресної соціальної допомоги наголошують, враховуючи власний досвід, і німецькі фахівці: “За умови обмежених бюджетних коштів життєво необхідно, щоб кошти, спрямовані на зменшення бідності, не потрапили помилково небідним домогосподарствам, а були адресно надані... [3]" тим, хто цього потребує.

Також, в Україні вже існують випадки повернення соціальних виплат в бюджет за недобросовісний характер їх отримання так званими “матерями-одиначками”, які фактично перебувають у шлюбі або сім'ями, що отримали допомогу на дитину і не доглядають за нею належним чи- 
ном і ін. І це підкреслює необхідність дотримання морально-етичного підходу до надання адресної соціальної допомоги.

Огляд наукової літератури з зазначеної проблематики показав, що автори Бухтіяров О. С., Данилюк О. І., Дідик С. М., Лібанова Е. М., Макарова О. М. та ін. одностайні в тому, що систему соціальних виплат і допомог в Україні потрібно удосконалювати задля досягнення соціальної ефективності суспільства.

Формулювання цілей. Однак, у суспільстві існує неодностайність у тому, яким чином досягати удосконалення системи соціальних виплат і допомог. Тому, метою статті є спроба удосконалення принципу соціальної справедливості при наданні адресної соціальної допомоги з точки зору морально-етичних підходів.

Виклад основного матеріалу. Загальновідомо, що принцип соціальної справедливості є актуальним для будь-якої країни і це питання не можливо вирішити один раз і назавжди, оскільки соціальні умови і соціальні можливості постійно змінюються. Успішні країни це, як правило, країни які знайшли прийнятний баланс впровадження принципу соціальної справедливості.

Сучасний словник 3 етики дає таке визначення поняття справедливості: "Справедливість - загальне співвідношення цінностей, благ між собою і конкретний розподіл їх між індивідами, належний порядок людського співжиття, який відповідає уявленням про сутність людини і ㄲi невід'ємні права ... Традиційно справедливістю вважають порядок співжиття людей, який відповідає гуманістичним уявленням про природу і сутність людини та їі невід'ємні права, про гармонійне узгодження потреб та інтересів особистості, суспільства і людства" [4].

Першим кроком у досягненні принципу соціальної справедливості в українському суспільстві був перехід від категорійного принципу надання соціальних допомог до адресного.

Наступним кроком був крок ліквідації ризиків непокриття - помилки виключення і витоку - помилки включення, що надало адресності більшої ефективності.

Наразі існує необхідність у врахуванні морально-етичних підходів при наданні адресної соціальної допомоги.

Оскільки суспільство є особливим і надзвичайно складним видом організації соціального життя, до складових суспільства відносяться соціальні інститути і соціальні спільноти, стійні соціальні взаємодії. Механізми саморегуляції суспільної системи дають змогу підтримувати іï цілісність, упорядковувати соціальні відносини між соціальними інститутами і соціальними спільнотами, репродукувати соціальні взаємодії.

Важливою складовою розвитку суспільства залишається якісна зміна структури суспільства, що включає в себе і зміну способу мислення як окремої людини, так і народу в цілому.

Цієї думки дотримуються, 3окрема, відомі українські вчені Бакуменко В. Д., Михненко А. М.: Під розвитком суспільства "звичайно розуміють лише такі зміни, які відповідають інтересам більшості, 
сприяють підвищенню якості життя людей і дають їм змогу впевненіше дивитися в майбутнє. Загальний механізм розвитку суспільства полягає у виникненні нових потреб у різних сферах суспільного життя та пошуку можливостей їх задоволення. Нові потреби постійно виникають як наслідок виробничої та іншої продуктивної діяльності людей, а тому пов’язані з пошуком та винаходом нових засобів праці, спілкування, організації суспільного життя, розширенням та поглибленням обсягу наукового знання, ускладненням форм і механізмів творчої діяльності людей... покращення системи суспільного управління на основі демократичних суспільних відносин забезпечує найкращі результати в удосконаленні суспільства та прискоренні його розвитку" [5].

Як українські дослідники, C. В. Кудлаєнко, так і громадські ініціативи, проект "Реформування системи пільг та привілеїв в Україні - наближення до європейських стандартів”, серед факторів, які перешкоджають впровадженню програм адресності називають непорозуміння груп інтересів, зокрема малозабезпечених громадян, які заміну пільг на адресну допомогу сприймають як позбавлення пільг.

Наказом MO3 України затверджено форми індивідуальної програми реабілітації інваліда, дитини-інваліда та Порядок їх складання [6].

Однак, соціальним працівникам знайома ситуація коли сім”і, які мають дитину-інваліда, або інваліда не зацікавлені у виконанні індивідуальної програми реабілітації бо в разі часткового або повного відновлення обмеження життєдіяльності, соціально-побутового стану, відновлення трудової діяльності зменшуються соціальні виплати.

Також, є приклади кримінальної поведінки особами, засобами до існування яких може бути саме адресна соціальна допомога [7].

Слід пам'ятати, що суспільство і його складові є соціальною системою, що виступають як системні цілісності.

Проблеми соціальних систем, їх природу вивчали такі видатні науковці як П. Бурдьє, Е. Гіденс, Р. Мертон, Т. Парсонс, Ю. Сурмін і ін.

Енциклопедичний словник з державного управління дає таке визначення цього поняття. Соціальна система: “...є складним організованим, упорядкованим цілим, яке складається 3 індивідів, соціальних спільнот та інститутів, що об'єднуються різноманітними зв’язками та відношеннями і мають соціальну природу. Основну роль у таких системах відіграють люди, які виступають суб'єктами соціальної діяльності. Соціальна система утворюється завдяки спільній меті, розумінню компонентами цієї системи своїх завдань та функцій. Значну роль у цій системі відіграють прямі та зворотні зв'язки, принцип ієрархії, соціокультурні стандарти, зразки поведінки тощо. Соціальна система характеризується високою здатністю до самоорганізації, активною діяльністю та адаптивністю. Природа соціальної системи зумовлена такими факторами, як тип цивілізації, рівень економічного, політичного, соціального та духовно-культур- 
ного розвитку, прояв людської активності. Соціальна система - різновид складних систем, які мають такі характеристики: поліструктурність, поліфункціональність, поліваріантність розвитку, тобто вони принципово багатоликі, багатоальтернативні, характеризуються множиною станів; недетермінованість, стохастичність і самодостатність; наявність механізмів цілевизначення, завдяки чому формуються цілі, програми, напрями руху; гнучкість, адаптивність, стійкість, здатність до виживання, збереження своєї самобутності...вони є органічними системами, які спроможні відновлювати елементи, структури, функції; характеризуються саморозвитком, саморегуляцією, самоуправлінням, самоорганізацією...”.

За такого підходу визначального значення набуває процес соціалізації як процес становлення особистості і поступового засвоєння нею вимог суспільства, суспільних норм і цінностей, включення до системи соціальних зв'язків і соціальних відносин, необхідних для життєдіяльності в певному суспільстві.

Відомо, що Д.Смелзер виділяє три фактори, необхідні для успішної соціалізації особистості:

- сподівання;

- зміна поведінки;

- прагнення відповідати цим сподіванням.

Тому, засвоєння кращих зразків соціального досвіду набуває рівня особистісних установок і орієнтацій.

Для кожної особи процес соціалізації є дуже індивідуальним i відбувається на усіх етапах життя, протягом якого людина інтегрується у суспільство, набуває рис індивідуальності, засвоює і використовує набуті цінності культури і поведінки.

Держава долучається до соціалізації особистості на рівні інституцій. Суспільство також встановлює норми і вимоги, які є складовими соціалізації особистості. За умови успішної координації всіх зусиль процес соціалізації особистості відбувається успішно.

Успішна соціалізація кожної особистості забезпечує соціальну безпеку всього суспільства.

Соціальна безпека суспільства є життєво важливим станом як окремої людини, так і всього суспільства. Соціальна безпека суспільства характеризується врівноваженою системою соціальних умов діяльності людини, захищеністю від впливу соціальних ризиків.

Науковці виділяють такі напрями соціальної політики, яка спрямована на формування соціальної безпеки у суспільстві:

- створення умов для підвищення соціально економічної активності населення;

- застосування сучасних мотиваційних і стимулюючих механізмів високопродуктивної праці;

- забезпечення достатнього життєвого рівня кожної людини на основі здійснення зваженої активної політики доходів;

- упровадження гнучкої, динамічної системи оплати праці;

- формування динамічної, гнучкої системи соціального захисту;

- розробка і впровадження у практику нової моделі соціального страхування; 
- реформування системи пенсійного забезпечення;

- реформування системи соціальної допомоги, посилення їі адресності;

- удосконалення системи соціальних послуг;

- здійснення соціальної підтримки сім'і, жінок, дітей, молоді;

- створення умов для розвитку меценатства, благодійницької діяльності;

- глибока структурна реформа державної житлової політики;

- реформування системи охорони здоров’я населення;

- захист громадян як споживачів послуг.

Оскільки соціальна політика включає в себе комплекс заходів і проводиться в різних напрямках розвитку соціальної сфери задля досягнення загального добробуту i надання соціальної захищеності усім без винятку верствам населення.

Основними функціями держави у проведенні соціальної політики є:

- соціальне відтворення населення, змістом якої є створення умов для нормальної життєдіяльності людини, задоволення ㄲï потреб у таких сферах суспільного життя, як праця, споживання, сімейні відносини, охорона здоров’я, освіта тощо;

- регулятивна, яка полягає в намаганні держави стимулювати активну діяльність особистості, соціальних груп за допомогою правових, економічних, моральних важелів, внаслідок чого люди стають здатними до самоорганізації та самозахисту;

- соціально-захисна, з якою пов’язані соціальні гарантії держави, забезпечення соціальних прав громадян у разі зниження матеріального рівня життя, втрати роботи, працездатності, старіння, інших ситуацій, які супроводжують людину від народження до смерті;

- стабілізаційно-адаптивна, згідно з якою держава має дотримуватися принципу соціальної справедливості, враховувати в своїй політиці реакцію населення, громадську думку, підтримувати свій авторитет серед населення, впливати на формування ціннісної свідомості суспільства, узгоджувати інтереси, регулювати правовими засобами конфлікти в суспільстві, забезпечуючи його усталений розвиток.

Тому соціальна політика $є$ системою управлінських, регулятивних, саморегулятивних способів та форм діяльності суб'єктів, сукупність принципів, рішень, дій, що втілюються в соціальних програмах і соціальній практиці з метою задоволення соціальних потреб, збалансування соціальних інтересів людини, соціальних груп суспільства, досягнення соціальних цілей, вирішення соціальних завдань, формування соціальних цінностей.

В широкому розумінні соціальна політика - це система інституційних і надінституційних, державних i громадських, суспільних і особистих, індивідуальних способів і форм діяльності, спрямованих на створення умов для всебічної самореалізації соціального потенціалу людини, ii сутнісних спроможностей, пишуть Скуратівський В. А., Михненко А. М., Макаренко Е. М.

Сучасні тенденції до укріплення соціальних зв'язків і соціального партнерства 3 представниками 
розвинених країн світу дають уяву про взаємозв'язок усіх прошарків суспільства в цих країнах, зокрема в питаннях соціального захисту.

Громадяни розвинених країн світу демонструють нам інші зразки поведінки. В успішних країнах світу звертатися за соціальною допомогою вважається принизливим і адресна соціальна допомога призначається, як правило, після вичерпання всіх можливих варіантів самостійного пошуку вирішення своїх фінансових проблем.

Саме такий принцип є морально-етичною основою надання адресної соціальної допомоги в розвинених країнах світу.

У цьому контексті архетипом принципу соціальної справедливості є приклад одного з основоположників німецького економічного дива Людвіга Ерхарда (1897-1977) який 3 дитинства, після тяжкої хвороби мав каліцтво. В часи Першої світової війни був поранений, що призвело до погіршення фізичного стану і визнання Людвіга Ерхарда непридатним до фізичної праці.

Не маючи змоги займатися підприємництвом, Людвіг Ерхард успішно опановує теоретичні основи економіки і створює умови для поліпшення свого економічного становища всій Німеччині [8].

У розвинених країнах діє морально-етичний принцип отримання соціальних допомог на основі самооцінки.

Цей принцип діє на рівні самосвідомості. Людина, яка має право на пільги, соціальні виплати, інколи свідомо не оформляє ці виплати, вважаючи що це обмежує іiі амбіції на певні ролі у суспільстві.
Про це свідчать і виступи європейських колег на міжнародних конференціях. Зокрема вчених з Латвії на щорічних конференціях, які відбуваються в університеті Україна.

Так само в Україні, люди, які мають особистий досвід проживання i праці в розвинених країнах світу, нерідко вищезазначені питання отримання-неотримання адресних соціальних допомог вирішують саме на засадах самооцінки.

За чинним законодавством України звання Героя України дає право безкоштовного отримання комунальних послуг без сплати за квартирну плату та комунальні послуги. Однак, зі звітів Управлінь праці і соціального захисту населення в місті Києві видно, що є випадки самокритичного підходу до вищезазначених питань і правом безкоштовного отримання комунальних послуг без сплати за квартирну плату та комунальні послуги користуються не всі хто має на це право.

Слід підкреслити, що вищевказана поведінка у розвинених країнах є звичайною нормою життя.

В Україні, при визначенні права особи на отримання певної адресної соціальної допомоги морально-етичний принцип iiı надання не враховується. Усі громадяни, які формально мають право на отримання такої допомоги, отримують ї.

Висновки і перспективи подальших досліджень. 3 вищевикладеного можна зробити висновок, що варто було б застосовувати морально-етичний підхід до усіх громадян, які претендують на отримання соціальних допомог, зокрема адресних, i при оформленні такої допомоги 
звертати увагу на морально-етичну і культурну складову претендента на соціальну допомогу для відновлення принципу соціальної справедливості iii надання. Зокрема, за запитом до правоохоронних органів. Якщо соціальна поведінка не відповідає загальноприйнятим стандартам поведінки, пропонується замінити адресну соціальну допомогу непривабливими для суспільства роботами з виховною метою, метою дотримання принципу соціальної справедливості і надання засобів до існування.

Перспективою наукових пошуків може бути подальше обговорення вищезазначених питань.

\section{СПИСОК ВИКОРИСТАНИХ ДЖЕРЕЛ}

1. Керівництво Мінсоцполітики взяло участь у Міжнародній конференції "Універсальні грошові виплати та виплати сім'ям 3 дітьми” 8 лютого 2019. URL: https://www.msp.gov.ua/ news/16674.html? PrintVersion (дата звернення 03.09.2019).

2. Макарова О. В. Соціальна політика в Україні: Монографія / О. В. Макарова // Ін-т демографії та соціальних досліджень ім. М.В. Птухи НАН України. - К. - 2015. - 244 с.

3. Принципи і способи функціонування адресної соціальної допомоги: рекомендації для України. URL: http:// www.ier.com.ua/files/publications/ Policy_papers/German_advisory group/2008/pp_07_2008_ur.pdf (дата звернення 05.09.2019).

4. Тофтул М. Г. Сучасний словник 3 етики: Словник. - Житомир: Видво ЖДУ ім. І. Франка, 2014. - 416 с.

5. Енциклопедичний словник 3 державного управління / уклад.:
Ю. П. Сурмін, В. Д. Бакуменко, А. М. Михненко та ін.; за ред. Ю. В. Ковбасюка, В. П. Трощинського, Ю. П. Сурміна. - К. : НАДУ, 2010. - С. 646.

6. Про затвердження форм індивідуальної програми реабілітації інваліда, дитини-інваліда та Порядку їх складання. Наказ МОЗ України від 08.10.2007 № 623. URL: https:// zakon.rada.gov.ua/laws/show/z119707 (дата звернення 06.09.2019).

7. Викрадення немовляти на Київщині. URL: https://youtu.be/Rk6WdDW9itI (Дата звернення 24.10.2019).

8. Батько економічного дива у товаристві контрольованої раціональності та раціонального самоконтролю. URL: https://dt.ua/ SOCIETY/batko_ekonomichnogo_ diva_u_tovaristvi_kontrolovanoyi_ratsionalnosti_ta_ratsionalnogo_ samokontrolyu.html (Дата звернення 07.09.2019).

\section{REFERENCES}

1. Kerivnytstvo Minsotspolityky vzialo uchast' u Mizhnarodnij konferentsii “Universal'ni hroshovi vyplaty ta vyplaty sim'iam z dit'my" 8 liutoho 2019 [The leadership of the Ministry of Social Policy participated in the International Conference "Universal cash payments and payments to families with children" on February 8, 2019] (n.d.). www.msp.gov.ua. Retrieved from https://www.msp.gov. ua/news/16674.html? PrintVersion [in Ukrainian].

2. Makarova O. V. (2015). Sotsial'na polityka v Ukraini [Social Policy in Ukraine]. In-t demohrafii ta sotsial'nykh doslidzhen' im. M. V. Ptukhy NAN Ukrainy. - K. [in Ukrainian].

3. Pryntsypy i sposoby funktsionuvannia adresnoi sotsial'noi dopomohy: 
rekomendatsii dlia Ukrainy [Principles and ways of functioning of targeted social assistance: recommendations for Ukraine]. (n.d.). www.ier.com.ua. Retrieved from http://www.ier.com. ua/files/publications/Policy_papers/German_advisory_group/2008/ pp_07_2008_ur.pdf [in Ukrainian].

4. Toftul M. H. (2014) Suchasnyj slovnyk z etyky: Slovnyk [Modern Ethics Dictionary: Dictionary]. Zhytomyr: Vyd-vo ZhDU im. I. Franka. [in Ukrainian].

5. Yu.P. Surmin, V.D. Bakumenko, A.M.Mykhnenko ta in. (2010). Entsyklopedychnyj slovnyk z derzhavnoho upravlinnia [Encyclopedic Dictionary of Public Administration]. K.: NADU. [in Ukrainian].

6. Pro zatverdzhennia form indyvidual'noi prohramy reabilitatsii invalida, dytynyinvalida ta Poriadku ikh skladannia. Nakaz MOZ Ukrainy vid 08.10.2007 № 623 [On approval of forms of the in- dividual program of rehabilitation of a disabled person, a disabled child and the Procedure for their preparation. Ministry of Health of Ukraine Order No. 623 of 08.10.2007] (n.d.). zakon.rada.gov. ua. Retrieved from https://zakon.rada. gov:ua/laws/show/z1197-07 [in Ukrainian].

7. Vykradennia nemovliaty na Kyivschyni [Baby abduction in Kyiv region]. (n.d.). youtu.be. Retrieved from https://youtu.be/Rk6WdDW9itI [in Ukrainian].

8. Bat'ko ekonomichnoho dyva u tovarystvi kontrol'ovanoi ratsional'nosti ta ratsional'noho samokontroliu [The father of economic miracle in the society of controlled rationality and rational self-control] (n.d.). dt.ua. Retrieved from https://dt.ua/SOCIETY/batko_ekonomichnogo_diva_u_tovaristvi_kontrolovanoyi_ratsionalnosti_ta_ratsionalnogo_samokontrolyu. html [in Ukrainian]. 